\title{
NEGATIVE REPRESENTATION OF ASSAD'S REGIME IN CNN ONLINE ARTICLES
}

\author{
Gina Nanda Utama ${ }^{1}$ \\ 1(Universitas Padjadjaran/ginananda07@gmail.com) \\ Rosaria Mita Amalia ${ }^{2}$ \\ ${ }_{2}^{2}$ (Universitas Padjadjaran / amelsasing@gmail.com)
}

\begin{abstract}
This research article discusses the use of chemical weapons in Syria. This study discusses the representation of Assad's regime in two CNN articles since there is an assumption that Assad's regime and its alliances are the responsible ones for the chemical weapon issue in Syria. The data is analyzed through Critical Discourse Analysis by Van Dijk as the grand theory so that it is examined by using macro and micro level analysis. This study shows that these articles present the negative representation of Assad's regime. It can be seen from the negative lexical choices which are used by the writers to describe Assad's regime and it also can be seen from the writers attempts to present the US's arguments by trying to legitimize it by frequently using verbal reaction in schematic analysis and the writers of the articles also struggle to hide another version of truth which stated that the responsible one for the use of chemical weapon in Syria is the rebels groups.
\end{abstract}

Keywords:

Assad's regime representation; critical discourse analysis; negative representation

DOI: $10.19105 /$ ojbs.v13i1.2262

\section{A. Introduction}

This study examines the representation of President of Syria Bashar al-Assad concerning the issue of the use of chemical weapons in Syria which is reported by two online articles in CNN. The first online article entitled "Syrian regime 'highly likely' to blame for the chemical attack, UK says" and the

1 CNN, "Syria 'highly Likely' to Blame for Chemical Attack, UK Says," accessed April 13, 2018,

https://edition.cnn.com/2018/04/12/middleeast/ukfrance-support-us-syria-airstrikes-int//index.html. second article entitled "Gunfire at UN team in Syria stalls chemical weapons inspection".2 Both of the online articles are examined by using Critical Discourse Analysis.

The conflict in Syria is one of the most complicated conflicts in the world since it does not only involve the Syrian government and its rebel, but there is also any foreign intervention, where

\footnotetext{
2 CNN, "Gunfire on UN Team Stalls Chemical Weapons Inspection," accessed April 13, 2018, https://edition.cnn.com/2018/04/18/middleeast/syr ia-opcw-inspectors-intl/index.html.
} 
Assad's regime is backed by other great countries such as Russia and Iran. Assad's regime has been accused of doing war crime towards the innocent civilians by using the chemical weapon in war. The international world responds it as one of the extraordinary war crimes since the main function of government is to protect its civilians, not to kill them.

Some countries such as the United State, France, and the UK believed that Assad's regime responsible for the use of chemical weapons in Syria. Moreover, they claimed that they have the evidence to prove that Assad's regime has done war crime. On the other side, Assad's regime and its alliances (Russia and Iran) have refused the claim and stated that the issue is intentionally created by the militant for getting sympathy from the world. Therefore, it can be seen that the US and its alliances (France and UK) accused Assad's regime to do the war crime but in contrast, Assad's regime also refused the accusation. This research investigated the representation of Assad's regime in CNN online articles about the use of chemical weapon in Syria. CNN is one of the biggest media in the US and it also becomes one of the news references which are accessed by many people in the US and also people around the world.

Van Dijk $^{3}$ described that Critical Discourse Analysis (CDA) is a kind of discourse analytical research which

\footnotetext{
3 Teun Adrianus Van Dijk, Discourse as Social Interaction, vol. 2 (London: SAGE Publications, 1997).
}

mainly focuses on examining the use of social power, dominance and inequality which is produced or opposed by the text or the talk in social or political context. CDA is one of the ways for the analyst to reveal the real identity of the object. An object in discourse cannot stand alone without context since context can determine the object's identity. Moreover, there is always any motive for every news release, so that by analyzing discourse by using CDA we can find out the ideology which is used to present the news. Eriyanto ${ }^{4}$ stated that one of the most influential agents to define a group is media since media can continuously release the issues which have built and shaped the audiences' understanding or awareness of a particular phenomenon. In conclusion, a discourse which is built by the media can influence the audiences' view of something by doing neutralization or marginalization. ${ }^{5}$

Van Dijk stated that in the text and talk production, it is necessary to know that the mental process can be established by the structure of the specific discourse or the production of specific social representation which can be promoted. ${ }^{6}$ In his approach, Van Dijk consolidates three dimensions of

\footnotetext{
${ }^{4}$ Eriyanto, Analisis Wacana: Pengantar Analisis Teks Media (Yogyakarta: LKiS, 2001).

5 Fajri P. Irfan, "Representasi Negatif Presiden Joko Widodo Dalam Artikel The Daily Mail Terkait Konflik Antara KPK Dan Polri: Analisis Wacana Kritis" (Unpublished Thesis, Universitas Padjajaran, 2016).

${ }^{6}$ Van Dijk, Discourse as Social Interaction.
} 
discourse such as social context, social cognition, and text. Sobur (as cited in Safitri) ${ }^{7}$ described that Van Dijk also categorizes discourse structure into three levels, the first is text dimension. In the text dimension, the analysis concerns the specific theme which can be reflected by the structure of the text. The second level is social cognition dimension, which focuses on the involvement of individual cognition of the reporter in producing the news. The third level talks about the formation of discourse which concerns with the issue which is developed in the society.

Van Dijk also categorizes discourse structure into three levels: macrostructure, superstructure and microstructure. $^{8} \quad$ Macrostructure is considered as the general comprehension of the text which can be investigated through the theme or the topic. The microstructure is the textual analysis of the text such as the sentences, style, or the selection of words which are used in the text. The superstructure is also called as a schematic structure which can show the arrangement of the part of the text.

This study has aim to reveal how these two articles represent Bashar Assad concerning the chemical weapon

\footnotetext{
7 Dessy Safitri, "A Critical Discourse Analysis of Racism in NBC News Online Mass Media of Michael Brown Case in Ferguson Missouri" (Thesis, UIN Sunan Ampel Surabaya, 2015), 16.

8 Teun Adrianus Van Dijk, Macrostructures: An Interdisciplinary Study of Global Structures in Discourse, Interaction, and Cognition (New Jersey: Lawrence Erlbaum Associates Publishers, 1980), 13.
}

issue by analyzing it in macro and micro level analysis, so that it is expected that this paper shows clearly about the writers/CNN's view or ideology concerning this phenomenon through critical discourse analysis which is supported by the linguistic pieces of evidence in both of the articles.

\section{B. Method}

The data of this study were obtained from CNN online articles concerning the chemical weapon issue in Syria. The writer chose two online articles entitled "Syrian regime 'highly likely' to blame for the chemical attack, UK says" and "Gunfire at UN team in Syria stalls chemical weapons inspection"10 since both of the articles elaborated more about the involvement of Assad's regime in chemical weapon issue.

The data were analyzed by using Van Dijk's theory of Critical Discourse Analysis, the writer analyzed and classified the data based on macro and micro (textual) analysis level to show elements and aspects which were used by the article writers in representing Assad's regime and its alliances negatively concerning the chemical weapon issues in Syria. 


\section{Results}

\section{Macro Level Analysis}

\section{a. Power}

Van Dijk described that power involves control of one party over others and this control relates to action and cognition so that this party can limit others by utilizing his great power, and as the result, they can successfully influence others' thoughts. ${ }^{11}$ Therefore, it can be seen that power has the ability to limit others how to judge, assess and face something. CNN's power can be seen in its communication event (one-way communication).

The power practice of CNN is shown by the way CNN represented Assad's regime in chemical weapon conflict. The power of CNN online articles is also presented when this online news is able to make the planning and control the news release about Assad's regime to show the negative representation of Assad's regime. In this part, CNN online articles have the potential chance to control and to influence the audiences' mind. It is in line with van Dijk who stated that the power of media is very symbolic and persuasive which means that the media has great control to influence the readers' minds or

11 Teun Adrianus Van Dijk, Principle of Critical Discourse Analysis (London: SAGE Publications, 1993). thoughts. ${ }^{12}$ In addition, according to van Dijk: "Power is based on privileged access to valued social resources, such as wealth, jobs status or indeed, preferential access to public discourse and communication". ${ }^{13}$

Moreover, Ghofur also adds that CDA may cause social groups to fight and propose their own ideologies so that the concept of assuming a discourse practice may represent ideological effects. ${ }^{14}$ In this case, the writers in these articles have great power to influence the readers and make the readers 'having the same thoughts or arguments with them'. Thus, it is much possible that the readers of these articles could have the same arguments that Assad's regime is war criminal since these two articles show the negative representation of Assad's regime, even though in fact, Assad's regime and its alliances strongly denied the accusation that he used the chemical weapon in war.

\footnotetext{
12 Teun Adrianus Van Dijk, Discourse Analysis as Ideology Analysis (Amsterdam: University of Amsterdam, 1995), 10.

${ }^{13}$ Teun Adrianus Van Dijk, Discourse, Power and Access. In C.R Caldas-Coulthard, \& M. Coulthard, Text and Practices. Readings in Critical Discourse Analysis (London: Routledge, 1996), 85.

14 Abd Ghofur, "Kontroversi Hukuman Mati Analisis Wacana Sastra Kritis the Life of David Gale Film Perspektif Sociocultural Practice Norman Fairclough," OKARA: Jurnal Bahasa dan Sastra 11, no. 1 (May 31, 2017): 197, https://doi.org/10.19105/ojbs.v11i1.1244.
} 


\section{b. Access Pattern}

\section{1) Planning}

CNN is one of the biggest and well known media in the United States, so that they have so many readers/ audiences. Related to this study, CNN articles assume that Assad's regime and its alliances have done the war crime to the innocent Syrian people by using the chemical weapon in war. When it is reported by CNN, it can be accessed by more people so that the news of Assad's regime and its alliances become interesting to discuss, but it does not mean that the articles are not valid or have a negative influence. In contrast, it has some interesting forms to investigate.

\section{2) Setting}

The great reputation of CNN makes them become one of the most influential media in the United States so that CNN has access to determine which references that will be used to produce and to release the news which will be presented to a large number of readers. Van Dijk explained that setting may be able to show and limit which participants who participate in the representation with a particular role and particular situation. ${ }^{15}$ In these two articles, we can see that CNN.COM highlighted Assad's regime as the agent for the cruelty in Syria by using a chemical weapon which has killed many civilians. In other words, the writers in these articles foreground the information that Assad's regime is a criminal and background another possibility which stated that Assad's regime is not the one who use chemical weapon.

\section{3) Controlling Communicative Events}

CNN online articles have full access to the controlling communicative events by determining how the news of the chemical weapon issue in Syria will be described and presented in its article. The genre of the article is a news report and the form of communication is one way oriented (media to the readers). The readers cannot argue against the news which is reported by CNN so that the media has full access to elaborate their arguments concerning the issues. The media also has access to present or to show some views and at the same time, they can

\footnotetext{
${ }^{15}$ Van Dijk, Discourse, Power and Access. In C.R Caldas-Coulthard, \& M. Coulthard, Text and Practices. Readings in Critical Discourse Analysis, 87.
} 
hide or marginalized other views. For instance, in the case of suspected chemical weapon in Syria, CNN articles only show or emphasize the view of US government and its alliances (France and UK) and there is almost no statement to strengthen or to emphasize the Assad's regime and its alliances' point of view.

In conclusion, CNN is not in a neutral position, which means it is contradictive to Assad's regime and its alliances' point of view. CNN also try to influence the readers to have the same view concerning the chemical weapon issue in Syria, so that the representation of Assad's regime and its alliances are described negatively in the CNN online articles. This one-way communication may cause the negative representation -of Assad's regime and its alliances- can be taken for granted by the readers as concrete truth without knowing the ideology behind the news.

\section{4) Scope and Audience Control}

CNN online articles do not have scope and audience control aspect since they cannot determine the range of audience who read the articles. But online versions enable more people to read the articles, not only US civilians but also all people around the world. CNN online articles' readers generally are adults and educated people since it is one of the greatest and most reputable media in the United States. It is also influenced by their contents which focus on news and serious topics and fields such as economics, politics, law etc. but in fact, CNN can do scope and audience control since they can damage the reputation of Assad's regime and its alliances representation in front of the readers since the content of the articles mainly talked about the negative representation of Assad's regime and its alliances in chemical weapon issue in Syria.

\section{Micro Level Analysis}

As described in the previous part that text consists of several structures/ levels (i.e. macrostructure, superstructure and microstructure) and they are related to each other.

\section{a. Macrostructure Analysis in Representing Assad's Regime Negatively Concerning the Chemical Weapon Issue in Syria in CNN Online Articles}

Macrostructure analysis is a level of analysis which investigates the global topic of the text. Van Dijk 
(as cited in Irfan) stated that global topic in the text can be found in the headline and lead of the articles, since we can find the topic which is presented as a dominant and central concept in headline and lead. ${ }^{16}$

Macrostructure analysis investigates the power of CNN which is shown through the headline and leadS on the articles entitled "Syrian regime 'highly likely' to blame for the chemical attack, UK says"17 and "Gunfire at the UN team in Syria stalls chemical weapons inspection". ${ }^{18}$

\section{b. Negative Representation of} Assad's Regime and Its Alliances on Macrostructure Analysis on Article Entitled "Syrian Regime 'Highly Likely' to Blame for Chemical Attack, UK Says"

Van Dijk said that the highest topic will be put in headline and lead since it enables any manipulation, such as decreasing some important information and change it with more detail or specific information. ${ }^{19}$ From the headline above, the power of CNN to make a negative representation of Assad's regime and its alliances concerning the chemical

16 Irfan, "Representasi Negatif Presiden Joko Widodo Dalam Artikel The Daily Mail Terkait Konflik Antara KPK Dan Polri: Analisis Wacana Kritis," 19.

17 CNN, "Syria 'highly Likely' to Blame for Chemical Attack, UK Says."

${ }^{18}$ CNN, "Gunfire on UN Team Stalls Chemical Weapons Inspection."

19 Van Dijk, Principle of Critical Discourse Analysis, 113. weapon issue can be clearly seen. The word "blame" clearly gives negative representation to Assad's regime which implies that Assad's regime is the one who responsible for the chemical attack in Syria. The headline also emphasizes the great possibility of Assad's regime involvement in chemical attack issue and marginalizes the possibility that he is not the responsible one since he has denied all of the accusations. In the article, the lead also strengthens the negative representation of Assad's regime by stating that the UK is getting ready for supporting US military action against Syria. Lead has a function to elaborate the headline. The lead in the first article is:

"The British government has signaled it is ready to back US military action against Syria, saying it is "highly likely" the Assad regime used chemical weapons on its own people and that such action could not go unchallenged"20

The lead stated the support of UK to US decision to do military action against Syria as the result it strengthens the negative representation of Syrian government that Assad's regime is the responsible one for the chemical attack in Syria. The lead also shows and emphasizes that it is not only US who assumed that the Assad's regime responsible

20 CNN, "Syria 'highly Likely' to Blame for Chemical Attack, UK Says." 
for the chemical attack, but another great country such as the UK also thought that it must be Assad's regime who do war crime which is shown by the expression "highly likely" which shows the high conviction. Moreover, CNN emphasizes more about the UK conviction by showing that the British government was ready to do real act to prove their conviction. In this study, we can also find that the writers of this article foreground information that Assad's regime is a war criminal, and at the same time the writers also background one of the most important information which st ated that the responsible one for the use of chemical weapon is the rebel groups. But as we can see, we cannot find any information about the rebel group in the headline and lead.

c. Negative Representation of Assad's Regime and Its Alliances on Macrostructure Analysis on Article Entitled "Gunfire at UN Team in Syria Stalls Chemical Weapons Inspection"

From the headline above we also can see the negative representation of Assad's regime, where the article seems to show or to inform that Assad's regimes try to disturb and threat the UN team in order to hide the evidence of the war crime. This assumption is also strengthened by the lead which stated:
"Chemical weapons experts who have been waiting for five days in Syria to inspect the site of a suspected gas attack were again delayed Wednesday, after gunfire at a UN security team forced it to turn back"21

The quote implies that there is any effort to disturb the chemical weapons inspection which is held by $\mathrm{UN}$, and the lead of this article also leads the reader to think or to assume that the one who responsible for the disturbance is the Assad's regime since they want to hide and lose the evidence.

\section{Superstructure Analysis}

As stated by van $\mathrm{Dijk}^{22}$, a text schema consists of summary which can be realized by a headline and lead elements, story (situation and comments), episode (main events and consequences), background (context and history) and verbal conclusions reactions (expectation and evaluation). Summary consists of the topic or main theme of the news and there must be the main content of the text in the summary. In addition, van Dijk described that superstructure has a function to describe the plot or the chronology of the news. ${ }^{23}$

Both texts show the negative representation of Assad's regime. Moreover, the lead of both paragraph also tries to present or to emphasize the

\footnotetext{
${ }^{21}$ CNN, "Gunfire on UN Team Stalls Chemical Weapons Inspection."

22 Van Dijk, Principle of Critical Discourse Analysis, 119.

${ }^{23}$ Van Dijk, 242.
} 
bad things of Assad's regime by presenting the ideas by stating that Assad's regime has used the chemical weapon (in the first text), and emphasizing the incident which is accused to Assad's regime (second text). Based on the schematic classification above, the verbal reaction is the most frequent pattern which is used by both of the articles' writers. The verbal reaction is used to strengthen and to emphasize the writers' argument by inserting the experts' opinion, personal opinion or descriptive event concerning the issue. In sum, it is the articles writers' strategy to hide their subjectivity.

\section{Microstructure Analysis on Semantic Level}

This analysis is used to know the instruments which are used for doing a negative representation of Assad's regime by using microstructure analysis. In this part, the main focus is the analysis of the word choices in a sentence or a clause and also the stylistic which is being implemented in the text. It is stated that the choice of word, sentence, and rhetorical proposition by the media is understood by van Dijk as a part of the media or writer's strategies.

\section{a. Level of Specificity, Degree of Completeness and Implicitness}

This part analyses the details which are used in the articles to support the negative representation in the articles entitled "Syrian regime 'highly likely' to blame for chemical attack, UK says" and "Gunfire at UN team in Syria stalls chemical weapons inspection"

Media can deliver the information implicitly to legitimize their version of truth and remove the truth version of others. The implicit information can be seen by examining the implication and presupposition in the text.

1) Text 1: "Syrian regime 'highly likely' to blame for chemical attack, UK says"

\section{Data 1}

"The British government has signaled it is ready to back US military action against Syria, saying it is highly likely the Assad regime used chemical weapons on its own people and that such action could not go unchallenged". ${ }^{24}$

"Ministers said there was need to deter the further use of chemical weapons by the Assad regime, and alleviate the humanitarian situation, a Downing Street statement said." 25

\section{Analysis of the Data 1}

Van Dijk stated that implications have significant role in discourses and communication since the reader can convey the meaning which is not literally stated in the text, and then it is important since such implications

\footnotetext{
24 CNN, "Syria 'highly Likely' to Blame for Chemical Attack, UK Says." ${ }^{25}$ CNN.
} 
can be inferred anyway, or they are not suitable with present communicative event, or because the writer chooses to background the implicit information. ${ }^{26}$

From the data above we can see that this article shows negative description or representation of Assad's regime by providing several opinions from the leaders of several great countries such as the UK. However, this negative representation which is shown by this article is based on opinions and probability. It can be seen from the use of 'highly likely' in the first data, according to Oxford Advanced Learner Dictionary 'highly' means or synonym to 'very' and 'likely' means 'probable or expected' which means that the argumentation is not based on the result of intensive investigation but it is still conducted from probability although the form 'highly likely' also has another literal meaning with or synonym to 'high conviction' but it is still a kind of probability. Although the arguments are not the products of the real confession from Assad or the result of actual investigation, all the negative information about Assad's regime in this article could lead and drive the readers to have the same argument with the writers' article which means the

26 Van Dijk, Principle of Critical Discourse Analysis, 109. reader could think or see Assad's regime as the war criminal.

\section{Data 2}

"According to the statement, May described the attack as a shocking and barbaric act which killed up to 75 people, including children, in the most appalling and inhumane way. Britain would work with United States and France to coordinate an international response, the statement said." ${ }^{27}$

"May spoke with US President Trump Thursday night about the international response to Syria, and they agreed that the Assad regime had established a pattern of dangerous behavior in relation to the use of chemical weapons, according to a Downing Street statement."28

"The UK Cabinet agreed Thursday that the Assad regime has a track record of the use of chemical weapons and it is highly likely that the regime is responsible for Saturday's attack," according to the Downing Street statement." ${ }^{\text {"29 }}$

\section{"While Turkish President Recep Tayyip Erdogan has condemned Assad for killing innocent kids in the Douma chemical attack, he also warned against using Syria as a place to flex military muscle." 30}

27 CNN, "Syria 'highly Likely' to Blame for Chemical Attack, UK Says."

${ }^{28}$ CNN.

${ }^{29} \mathrm{CNN}$.

${ }^{30} \mathrm{CNN}$. 


\section{Analysis of the Data 2}

The bold and underlined expressions above indicate the legitimation from other parties to emphasize and to pursue the reader that Assad's regime is the agent behind the chemical attack in Syria. It can be seen when the writer tries to influence the readers by providing many pieces of information concerning the impacts of chemical weapon attacks on victims.

In this article, the writers stated that Assad's regime is the most possible one who can do such terrible things. However, it is not based on the empirical investigation but it is based on opinions from some parties. One of the explicit evidence can be seen in the word choices in the second data, where we can find "they agreed...". In Oxford Advanced Learner Dictionary, the word "agree" (V) means "to have same opinion as somebody" so that we can see clearly that the argumentation is still a product of some great countries' point of view or opinion or it is not a result of direct investigation or Assad's confession. Moreover, in third data, we can find a sentence "Assad regime has a track record....". From this part of the clause, we can also infer that the main argument which is conducted in this article is not based on the actual evidence in the conflict in Douma, but it is still an opinion which is conducted from the previous events.

In addition, CNN chose to insert the Turkish President which recognized as the one who can be neutral for seeing the issues especially Turkey is one of the countries with a great number of Moslem populations to strengthen their legitimation so that it can strengthen their argument.

2) Text 2: "Gunfire at UN Team in Syria Stalls Chemical Weapons Inspection"

\section{Data 1}

"Chemical weapons experts who have been waiting for five days in Syria to inspect the site of a suspected gas attack were again delayed Wednesday, after gunfire at a UN security team forced it to turn back." 31

"Every day matters," he told CNN recently. The greater the time between when it's released and when it's detected, the chances of it being found reduces. ${ }^{32}$

\section{Analysis of the Data 1}

The underlined and bold expressions implied that there is any party who want to try to disturb the UN investigation of chemical weapon in Syria. In this lead, the agent is not directly mentioned, but

\footnotetext{
31 CNN, "Gunfire on UN Team Stalls Chemical Weapons Inspection."

${ }^{32}$ CNN.
} 
in the paragraph of the article, it is directly stated that the responsible one for the attack to the UN team is Assad's regime, as stated:

"The United States, the United Kingdom and France have blamed Syrian President Bashar al-Assad's regime for the attack and together carried out airstrikes over the weekend in response, with the support of other Western nations." 33

So that, this data also show or describe the negative representation of Assad's regime.

\section{Data 2}

"The US envoy to the OPCW, Kenneth Ward, said on Monday he was concerned Russia may have "tampered with" the site of the Douma attack." ${ }^{34}$

"Russia has openly announced that its representatives have been to the site, and a CBS journalist has also accessed the site, reporting from the location in recent days." 35

"Russian Foreign Minister Sergey Lavrov told the BBC's "HARDtalk" that he guaranteed there had been no Russian tampering, adding his country had sent experts to the site and found "no trace" of chemical weapons." 36

"The Russian military said Tuesday in state media it had discovered a chemical laboratory and warehouse in Douma allegedly run by "militants." CNN could not corroborate that allegation." ${ }^{17}$

\section{Analysis of Data 2}

From the data above we can see that in this article there is a negative representation of one of Assad's regime alliances which is Russia. From the data above, the article tries to show that there is any possibility of Russia's intervention to abolish the evidence of war crime by Assad's regime in Syria, moreover it is also strengthened by the next data that Russia's representatives have been to the site, so that it gives so much possibility for Russia to abolish the evident. In addition, the article also shows the contradictive fact of the Russian military finding of militant's chemical laboratory and warehouse by stating that CNN could not corroborate that allegation. Moreover, to emphasize the writer's doubtfulness, the writer used quotation mark in the word militant.

Based on the data above, we can see that both of the text strengthen and emphasize the negative representation of Assad's regime, since there are so many propositions indicated Assad's regime has done the war crime by using chemical weapon. Moreover, in both the articles, we can find some negative

${ }^{37} \mathrm{CNN}$. 
propositions which highlighted that Assad's regime is the cruel government who can kill the innocent civilians. On the other side, we know that Assad's regime has refused the claim that they are the responsible one for the chemical attack for several times, moreover the Assad's regime stated that the chemical attack was done by the opposition to malign the Assad's regime. Therefore, from this perspective, there is still any possibility that Assad's regime is not the one who responsible for the attack (presumption of innocence) especially there is no really clear and direct evident which can show directly that Assad's regime responsible for the chemical attack, so that the news should be neutral by providing and comparing both of the perspectives and let the audience assess the phenomenon.

In contrary, these two CNN online articles did not expose exclusively about the opposition's possibility to do the chemical attack and they only show and strengthen continuously one point of view which 'believe' that Assad's regime is the responsible one for the chemical attack in Syria.

In these two articles, CNN tried to strengthen 'their believe' and try to influence and convince the audiences by providing the opinion from the third party which has the same point of view without comparing or considering another third party which has a different point of view with them. Therefore, we can see that CNN has done negative representation to Assad's regime concerning the chemical attack in Syria by only strengthening and emphasizing one point of view and hiding another from audience, especially the responsible one for chemical attack in Syria has not clearly confirmed yet since Assad's regime refuse the accusation so that it is still an assumption.

\section{b. Stylistic Aspect}

The focus analysis in stylistic aspect is the word choice. Van Dijk described that in the word choice level, we can use stylistics which impacts to conduct opinion in mental models. ${ }^{38}$ Lexical items choices in the press are used to describe people, actions or events based on the opinion attitude and the ideology from the journalist. Therefore, it indicated that the chosen words can describe attitude or ideology which relates to the events in the text and it also can show someone's interpretation of fact or reality (as cited in Irfan). ${ }^{39}$ In this aspect, the writer focuses on the lexical choices which are used by the mass media (CNN). In this aspect, the lexical choices are used to strengthen and to emphasize the negative representation of the object in the text.

38 Van Dijk, Principle of Critical Discourse Analysis, 121.

39 Irfan, "Representasi Negatif Presiden Joko Widodo Dalam Artikel The Daily Mail Terkait Konflik Antara KPK Dan Polri: Analisis Wacana Kritis," 27. 


\section{Data}

"According to the statement, May described the attack as a "shocking and barbaric act which killed up to 75 people, including children, in the most appalling and inhumane way." Britain would work with the United States and France to coordinate an international response, the statement said." 40

"May spoke with US President Trump Thursday night about the international response to Syria, and they "agreed that the Assad regime had established a pattern of dangerous behavior in relation to the use of chemical weapons," according to a Downing Street statement. ${ }^{41}$

"While Turkish President Recep Tayyip Erdogan has condemned Assad for killing "innocent kids in the Douma chemical attack," he also warned against using Syria as a place to flex military muscle." $" 42$

\section{Analysis}

In the article entitled "Syrian regime 'highly likely' to blame for the chemical attack, UK says" there are several lexical choices which have negative meaning such as barbaric act and dangerous behavior. Both of the negative expressions are referred to Assad's regime, the writers emphasize the negative representation of Assad's regime. Moreover, there is any negative expression condemned Assad which also strengthen the negative

40 CNN, "Syria 'highly Likely' to Blame for Chemical Attack, UK Says."

${ }^{41}$ CNN.

${ }^{42}$ CNN. representation of Bashar Al Assad in the articles.

As we can see that in the data there is agent deletion in the clause "May described the attack as a...". The writer of this article prefer to use the word "attack" as a noun, and this pattern allows the writer to hide the real agent of the action. When the writer chose the word "attack" as a verb, it requires the agent to be explicitly stated in the clause. Nevertheless, this agent deletion does not give positive representation to Assad's regime since the word "attack" is always attached to Assad's regime from the beginning of the articles so that the readers automatically refer the agent of attack as Assad's regime.

Moreover, in this data, we can find interesting word choices to describe and to represent Assad's regime such as barbaric act. According to Oxford Advanced Learner's Dictionary "barbaric" is an adjective which means "cruel and violent and not as expected from people who are educated and respect each other" and it is collocated with the word act $(\mathrm{N})$ which means "a particular thing that somebody does", It can be inferred that the writers of the articles try to show their interpretation or description of Assad's regime by providing the opinion from British Prime Minister Theresa May who described that Assad's regime has done terribly cruel and violent thing to human being. 
Therefore, we can see that the writers in this article provide negative representation of Assad's regime since they chose to insert the opinion from a country which accused and opposed Assad's regime, although, in fact, there are several countries who thought that Assad's regime is not the one who responsible for the chemical weapon issue in Syria such as Russia and Iran.

The next data also has the same pattern with the previous one since it used negative words to describe or to represent Assad's regime by inserting a phrase dangerous behavior in the data. In Oxford Advanced Learner's Dictionary, the word "dangerous" (adj) means "likely to injure or harm somebody, or to damage or destroy something" and "behavior" means "the way that somebody behaves, especially towards other people". It can be seen that the use of this phrase to describe Assad's regime can lead the readers to think that Assad's regime is a party who behaves very cruel towards the victims by injuring and harming them through destroying or damaging the victim's life. In addition, this data shows a negative representation of Assad's regime explicitly since it directly collocates the word Assad's with negative noun phrase "dangerous behavior".

The last data also strengthens the negative representation of Assad's regime since the writer of the articles inserts the opinion from Turkish
President who is famous for his compassion towards humanity. The use of Erdogan's opinion can strengthen cnn.com legitimation in these two articles that Assad's regime is the real war criminal. Moreover, in this data, we can find very strong Turkish President's reaction since we can find a word condemned in the data, the word "condemn" (v) means "to express very strong disapproval of somebody/something, usually for moral reasons". In addition, this word is not only used to criticize Assad's regime but this word is also put by the writers with another word which has negative meaning such as "killing" (v). Therefore, the writers of the cnn.com articles explicitly show the negative representation of Assad's regime in these articles.

\section{Conclusion}

After analyzing the CNN online articles concerning chemical weapon issues by using macro and micro level analysis, it can be concluded that the article writers show or deliver the negative representation of Assad's regime and its alliances. It can be seen from the negative lexical choices which are used by the writers to describe Assad's regime and its alliances, and it also can be seen from the writers' attempt to present the US's arguments and try to legitimize it by the frequent use of verbal reaction in a schematic analysis. 


\section{References}

CNN. "Gunfire on UN Team Stalls Chemical Weapons Inspection." Accessed April 13, 2018. https://edition.cnn.com/2018/04/1 8/middleeast/syria-opcwinspectors-intl/index.html.

. "Syria 'highly Likely' to Blame for Chemical Attack, UK Says." Accessed April 13, 2018. https://edition.cnn.com/2018/04/1 2/middleeast/uk-france-supportus-syria-airstrikes-intl/index.html.

Eriyanto. Analisis Wacana: Pengantar Analisis Teks Media. Yogyakarta: LKiS, 2001.

Ghofur, Abd. "Kontroversi Hukuman Mati Analisis Wacana Sastra Kritis the Life of David Gale Film Perspektif Sociocultural Practice Norman Fairclough." OKARA: Jurnal Bahasa dan Sastra 11, no. 1 (May 31, 2017): 193. https://doi.org/10.19105/ojbs.v11i 1.1244 .

Irfan, Fajri P. "Representasi Negatif Presiden Joko Widodo Dalam Artikel The Daily Mail Terkait Konflik Antara KPK Dan Polri: Analisis Wacana Kritis." Unpublished Thesis, Universitas Padjajaran, 2016.
Safitri, Dessy. "A Critical Discourse Analysis of Racism in NBC News Online Mass Media of Michael Brown Case in Ferguson Missouri." Thesis, UIN Sunan Ampel Surabaya, 2015.

Van Dijk, Teun Adrianus. Discourse Analysis as Ideology Analysis. Amsterdam: University of Amsterdam, 1995.

Discourse as Social Interaction. Vol. 2. London: SAGE Publications, 1997.

. Discourse, Power and Access. In C.R Caldas-Coulthard, \& $M$. Coulthard, Text and Practices. Readings in Critical Discourse Analysis. London: Routledge, 1996.

- Macrostructures: $\quad A n$ Interdisciplinary Study of Global Structures in Discourse, Interaction, and Cognition. New Jersey: Lawrence Erlbaum Associates Publishers, 1980.

—. Principle of Critical Discourse Analysis. London: SAGE Publications, 1993. 